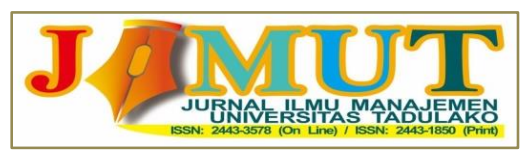

Vol. 6, No.3, September 2020, 243-251

\title{
PENGARUH PROMOSI DAN LINGKUNGAN TOKO TERHADAP PEMBELIAN TIDAK TERENCANA (IMPULSE BUYING) PADA HYPERMART DI KOTA PALU
}

\author{
SURYA NINGSIH \\ MASKURI SUTOMO \\ IRA NURIYA SANTI \\ Program Studi Manajemen, Fakultas Ekonomi, Universitas Tadulako \\ Email: survaningsih59736@gmail.com;maskuri.sutomo@yahoo.com; ira.nuriva@yahoo.com;
}

\begin{abstract}
The study aims to determine the influence of the promotion and environment of the store against unplanned purchases at Hypermart in Palu City. The research method used in this study was a causal descriptive method with the number of samples used by a total of 60 respondents. The analytical techniques used are multiple linear regression analyses and sample withdrawal forms using purposive sampling techniques. The results of this study showed that simultaneously the promotion and the environment of the store has an effect on the unplanned purchase of Hypermart in Palu City. Furthermore a partial promotion and store environment significantly affected the unplanned purchase of Hypermart in Palu City. This result is also supported by the acquisition of a correlation coefficient of $88,5 \%$ indicating a close relationship between the two variables with an uplanned purchase at Hypermart in Palu City. It is important for Hypermart to ensure that the implementation of the promotion and the store environment has been done well and precisely so that for the future can consistently create an unplanned purchase when visiting Hypermart in Palu City.
\end{abstract}

Keywords:Promotion, Shop Environment, Unplanned Purchases.

\begin{abstract}
ABSTRAK
Penelitian ini bertujuan untuk mengetahui pengaruh promosi dan lingkungan toko terhadap pembelian tidak terencana pada Hypermart di Kota Palu. Metode penelitian yang digunakan dalam penelitian ini adalah metode deskriptif kausal dengan jumlah sampel yang digunakan pada penelitian sebanyak 60 responden. Teknik analisis yang digunakan adalah analisis regresi linear berganda dan bentuk penarikan sampel menggunakan teknik purposive sampling. Hasil penelitian ini menunjukkan bahwa secara serempak promosi dan lingkungan toko berpengaruh signifikan terhadap pembelian tidak terencana pada Hypermart di Kota Palu. Selanjutnya secara parsial promosi dan lingkungan toko berpengaruh signifikan terhadap pembelian tidak terencana pada Hypermart di Kota Palu. Hasil ini juga didukung dari perolehan tingkat koefisien korelasi sebesar $88,5 \%$ menunjukkan adanya hubungan yang erat antara kedua variabel tersebut dengan pembelian tidak terencana pada Hypermart di Kota Palu. Penting bagi pihak Hypermart untuk memastikan bahwa penerapan promosi dan lingkungan toko telah dilakukan dengan baik serta tepat sehingga untuk kedepannya dapat secara konsisten menciptakan pembelian tidak terencana ketika mengunjungi Hypermat Kota Palu.
\end{abstract}

Kata Kunci:Promosi, Lingkungan Toko, Pembelian Tidak Terencana.

\section{PENDAHULUAN}

Perkembangan bisnis ritel di Indonesia sudah semakin pesat.Hal ini ditandai dengan keberadaan pasar tradisional yang mulai tergeser oleh munculnya berbagai jenis pasar modern, sehingga beberapa pusat perbelanjaan eceran bermunculan dengan berbagai macam bentuk dan ukuran.Bisnis ritel adalah aktivitas usaha yang menjual barang-barang kebutuhan sehari-hari baik dalam bentuk produk dan jasa yang ditujukan pada konsumen untuk kegunaan pribadi atau keluarga (Desrayudi, 2011). Maka dari itu, dengan semakin bertambahnya ritel modern akan membuat kompetisi antar ritel menjadi semakin ketat.

Pembelian terencana adalah perilaku pembelian dimana keputusan sudah dipertimbangkan sebelum masuk ke dalam toko, sedangkan pembelian tidak terencana adalah perilaku pembelian tanpa ada 


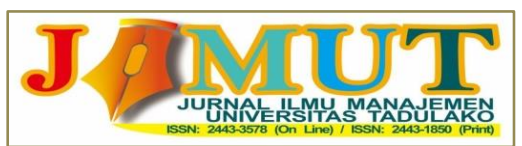

Vol. 6, No.3, September 2020, 243-251

pertimbangan sebelumnya. Salah satu jenis pembelian tidak terencana yang sering mendapatkan perhatian adalah pembelian impulsif (impulsive buying). Hal ini disebabkan adanya fenomena dan kecenderungan perilaku belanja meluas yang terjadi di dalam pasar dan menjadi poin penting yang mendasari aktivitas pemasaran.

Menurut Rook dan Fisher (1995, dalam Ria Arifianti, 2015) mendefinisikan impulse buying sebagai kecenderungan konsumen untuk membeli secara spontan, reflek, tiba-tiba dan otomatis. Sehingga dapat disimpulkan bahwa impulse buyingadalah sesuatu yang alamiah dan merupakan reaksi yang cepat.

Point of Purchase Advertising Institute (POPAI) malaporkan bahwa sekitar 75\% konsumen melakukan pembelian di supermarket secara tak terencana.Hal yang sama pun dapat dilihat di pasar Jepang seperti yang dilaporkan oleh The Distribution Economics Institute of Japan (DEI) bahwa sekitar 70\% konsumen Jepang sering melakukan pembeliaan yang tak terencana.

Dengan demikian, lebih banyak barang yang diinginkan untuk dibeli merupakan barang-barang yang dibeli secara tidak terencana (produk impulsif), dan bahkan barang-barang tersebut bagi konsumen terkadang tidak diperlukan, maka berdasarkan uraian latar belakang di atas peneliti tertarik untuk mengambil judul "Pengaruh promosi dan lingkungan toko terhadap pembelian tidak terencana (impulse buying) pada Hypermart di Kota Palu

\section{KAJIAN LITERATUR DAN PENGEMBANGAN HIPOTESIS}

\section{Manajemen Pemasaran}

Pemasaran dalam suatu perusahaan memegang peranan yang sangat penting, karena pemasaran merupakan salah satu kegiatan yang dilakukan untuk mempertahankan kelangsungan hidup perusahaan dan sebagai salah satu faktor untuk kesuksesan perusahaan banyak ditentukan oleh prestasi dibidang pemasaran seperti proses mempelajari kebutuhan dan keinginan konsumen serta memuaskan konsumen dengan produk dan pelayanan yang baik dengan tujuan memperoleh laba. Menurut Hasan (2013: 4). "Pemasaran adalah proses mengidentifikasi, menciptakan dan mengkomunikasikan nilai, serta memelihara hubungan yang memuaskan pelanggan untuk memaksimalkan perusahaan.Manajemen pemasaran merupakan "Analisis, perencanaan, implementasi, dan pengendalian program yang dirancang untuk menciptakan, membangun, dan mempertahankan pertukaran yang menguntungkan dengan pembeli sasaran demi mencapai tujuan organisasi”.

\section{Bauran Pemasaran}

Salah satu kunci memenangkan persaingan bisnis adalah melalui sistem pemasaran yang baik dimana untuk mengefektifkan tujuan pemasaran, bagian pemasaran perlu mempunyai strategi untuk menunjang visi dan misi perusahaan tersebut melalui strategi bauran pemasaran.Bauran pemasaran akan membantu perusahaan untuk menentukan suatu produk atau jasa yang diinginkan oleh para konsumennya, menentukan harga yang tepat untuk sebuah produk yang telah diciptakan oleh perusahaan, menentukan saluran distribusi untuk penyampaian produk sampai ke tangan konsumennya dengan mudah, serta perusahaan akan tahu cara mempromosikan produk atau jasa sehingga dapat dikenal dan dikonsumsi oleh konsumennya.Menurut Kotler dan Armstrong (2014:76) menyatakan bauran pemasaran adalah seperangkat alat pemasaran yang terdiri dari produk, tempat, harga dan promosi yang digunakan perusahaan untuk menghasilkan respon yang diinginkan pasar sasaran. Dari definisi tersebut maka dapat disimpulkan bahwa bauran pemasaran merupakan alat pemasaran yang baik yang berada dalam suatu perusahaan, dimana perusahaan mampu mengendalikan agar dapat mempengaruhi respon pasar sasaran.nama merek atau beberapa makna produk lainnya.

\section{Promosi}

Dalam berbisnis, penting bagi setiap kegiatan usaha untuk melakukan proses pemasaran yaitu menginformasikan keberadaan usaha kita kepada masyarakat dan konsumen potensial. Promosi pada hakikatnya adalah suatu bentuk komunikasi pemasaran yang bertujuan untuk mendorong permintaan.Artinya melalui komunikasi, seperti halnya mempromosikan suatu produk yang dapat menarik perhatian konsumen untuk segera mengambil keputusan untuk membeli produk yang ditawarkan bahkan tidak di rencanakan sekalipun.Menurut Peter dan Olson (2014:224) menyatakan tujuan promosi adalah (1) mempengaruhi perilaku untuk mengubah atau memelihara perilaku tertentu konsumen yang berkaitan dengan produk atau merek, (2) memberi informasi, menciptakan 


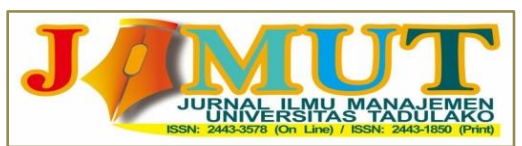

Vol. 6, No.3, September 2020, 243-251

pengetahuan, kepercayaan atau makna baru tentang produk atau merek dalam benak konsumen, (3) membujuk untuk mengubah perilaku, kepercayaan, dan keinginan konsumen terhadap sebuah produk atau merek, (4) mentransformasi tanggapan afeksi, memodifikasi perasaan, citra, dan emosi yang diaktifkan ketika konsumen mempertimbangkan produk atau merek, (5) mengingatkan untuk meningkatkan potensi aktifitas dari nama merek atau beberapa makna produk lainnya.

\section{Lingkungan Toko}

Penataan lingkungan toko dapat menimbulkan beberapa manfaat seperti membantu mengarahkan perhatian kosumen (dalam hal ini erat kaitannya dengan memperbesar ketertarikan mereka), menggerakkan reaksi dan emosi konsumen, serta memperhatikan konsumen seperti apa yang disasar agar bisa menentukan positioning sebuah toko. Menurut Utami (2010:255) mengemukakan bahwa lingkungan toko merupakan segala hal yang berkaitan dengan toko, seperti desain, tata letak, warna, musik, pencahayaan dan aroma dalam menciptakan kesan dan citra yang dapat menarik minat konsumen. Salah satu hal penting bagi toko ritel yang diperkuat bahwa lingkungan toko dapat memberikan suatu kesenangan bagi para konsumen dalam berbelanja, tetapi juga dapat memberikan suatu nilai tambah dari konsumen terhadap produk-produk yang dijual ditoko.

\section{Perilaku Konsumen}

Perilaku konsumen merupakan salah satu hal yang layak untuk diketahui, dipahami, dan diantisipasi oleh setiap orang yang bergerak dalam bisnis ritel. Karena setiap peritel harus mengetahui berbagai pola dan gaya belanja setiap konsumen. Menurut Sciffman dan Kanuk (2010: 7) menjelaskanperilaku konsumen sebagai perilaku yang diperlihatkan konsumen dalam mencari, membeli, menggunakan, mengevaluasi dan menghabiskan produk atau jasa yang mereka harapkan akan memuaskan kebutuhan mereka. Mempelajari perilaku konsumen bagi perusahaan adalah memungkinkan perusahaan memahami dengan tepat kebutuhan dan keinginan pelanggannya sehingga dapat membantunya untuk memuaskan pelanggan.

\section{Keputusan Pembelian}

Menurut Kotler dan Armstrong (2014:158) menjelaskan bahwaperilaku pembelian konsumen akhir, baik individu maupun rumah tangga, yang membeli barang dan jasa untuk konsumsi secara pribadi. Terkadang keinginan yang dapat membuat konsumen untuk membeli suatu produk yang sering kali harus dibatalkan karena berbagai alasan, seperti (1) Pembelian yang terencana sepenuhnya, pembelian ini terjadi dikarenakan jika konsumen sudah menentukan pilihan produk dan merek jauh sebelum pembelian dilakukan. (2) Pembelian yang separuh terencana, yang mana pembelian ini terjadi ketika konsumen mengetahui ingin membeli suatu produk namun mereka tidak mengetahui merek yang akan dibelinya dan sampai mereka bisa memperoleh informasi dari pramuniaga di toko tersebut. (3) Pembelian yang tidak terencana, dimana pembelian impuls dapat terjadi ketika konsumen membeli suatu produk tanpa direncanakan sebelumnya misalnya dikarenakan adanya pemotongan harga ataupun diskon yang membuat konsumen tertarik sehingga dapat menyebabkan kegiatan pembelian. (4) Proses pembelian, pada tahap ini terjadi beberapa perilaku yang meliputi mencari informasi dan mengambil data artinya seorang konsumen akan mencari informasi mengenai produk, merek atau toko yang tentunya dari berbagai sumber seperti majalah, televisi, radio dan bahkan mendapatkan informasi dengan berkomunikasi melalui teman.

\section{Ritel Modern}

Berbelanja di toko ritel modern saat ini sudah menjadi bagian dari gaya hidup masyarakat indonesia. Pola perilaku belanja pelanggan yang sedikit demi sedikit berubah, perlu direspon secara aktif oleh peritel untuk dapat mempertahankan keberlanjutan usahanya dalam jangka panjang.Menurut Kotler dan Keller (2012:447) menjelaskan bahwa ritel mencakup semua kegiatan dalam menjual barang atau jasa secara langsung kepada konsumen akhir untuk penggunaan pribadi dan non bisnis.Pengecer atau toko eceran adalah perusahaan bisnis yang volume penjualan utamanya berasal dari ritel.Kelebihan yang ditawarkan oleh ritel modern bukan hanya ketersediaan barang tetapi ritel modern juga mampu memenuhi aspek psikologis konsumen.Misalnya menyangkut keamanan, kenyamanan, dan kebersihan. 


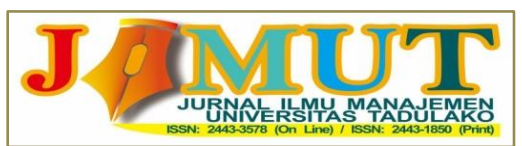

Vol. 6, No.3, September 2020, 243-251

\section{Pembelian Tidak Terencana (Impulse Buying)}

Pembelian tidak terencana merupakan perilaku pembelian dimana konsumen tidak mempertimbangkan untuk membeli, atau mempertimbangkan untuk membeli tetapi belum memutuskan produk atau barang apa yang akan dibeli. Menurut Utami (2010:67) mengatakan bahwa pembelian impulsif terjadi ketika konsumen tiba-tiba mengalami keinginan yang kuat dan kukuh untuk membeli sesuatu secepatnya.Pembelian impulsif atau sering disebut dengan pembelian tidak terencana merupakan bentuk lain dari pola pembelian konsumen yang tidak secara spesifik terencana. Pembelian tidak terencana terjadi ketika konsumen memiliki keinginan yang kuat untuk membeli sesuatu dengan cepat.Pembelian tidak terencana juga terjadi pada produk harga tinggi cenderung sangat sulit karena terkait dengan resiko yang dihadapi jadi memerlukan perencanaan contohnya membeli smartphone dan mobil, konsumen tidak akan langsung melakukan pembelian melainkan akan mencari informasi terlebih dahulu. Namun, cenderung dilakukan dengan mengabaikan pertimbangan atas konsekuensinya. Seseorang dengan emosi yang positif menyebabkan orang tersebut memiliki gairah dalam berbelanja. Berbagai produk yang dinilai menarik akan dibeli meskipun tidak ada perencanaan sebelumnya. Orang tersebut menganggap bahwa pembelian yang dilakukan merupakan pelampiasan dari rasa senang yang dialaminya.melalui teman.

\section{Hubungan Antar Variabel \\ Pengaruh Promosi Terhadap Pembelian Tidak Terencana}

Tujuan dari promosi sangat beragam, melalui promosi perusahaan dapat menarik konsumen baru, meningkatkan volume penjualan dengan menciptakan tampilan dan aktivitas yang menarik untuk memicu pembelian tidak terencana. Promosi merupakan salah satu elemen penting dari bauran pemasaran karena dengan adanya promosi maka suatu produk atau jasa yang dihasilkan dapat diketahui oleh konsumen dengan berbagai alat media elektronik maupun cetak.

Berdasarkan hasil penelitian yang dilakukan Kharis (2011), bahwa terdapat pengaruh yang positif dan signifikan dari promosi terhadap impulse buying. Penelitian ini juga diperkuat dengan penelitian yang dilakukan oleh Sari dan Suryani (2014) yang menyatakan bahwa semakin baik tingkat kegiatan promosi yang dilakukan makan akan meningkatkan pembelian impulsif.

\section{Pengaruh Lingkungan Toko Terhadap Pembelian Tidak Terencana}

Lingkungan toko merupakan suasana yang harus dibuat semenarik mungkin untuk mempengaruhi konsumen dalam melakuikan pembelian. Ketika Hypermart mampu menciptakan lingkungan toko yang menarik, baik dalam hal kerapian dan tata letak yang memudahkan konsumen mengetahui produk yang diinginkan dan dibutuhkan, maka didiga lingkungan toko dapat memicu perilaku pembelian tidak terencana.

Sari dan Suryani (2014) dari hasil penelitiannya menunjukkan bahwa penciptaan suasana pada lingkungan gerai yang baik akan meningkatkan pembelian impulsif. Penelitian ini juga sejalan dengan penelitian yang dilakukan oleh Leba dan Suhermin (2015) yang menyatakan atmosfer gerai berpengaruh positif dan signifikan terhadap pembelian impulsif, hal ini dapat diartikan semakin baik atmosfer gerai akan meningkatkan pembelian impulsif.

\section{METODE PENELITIAN}

\section{Jenis Penelitian}

Penelitian ini bersifat deskriptif kausal dengan alasan peneliti akan menggambarkan secara sistematis sejauh mana hubungan serta pengaruh dari variabel independen promosi dan lingkungan toko terhadap variabel dependen yaitu pembelian tidak terencana pada konsumen Hypermart di Kota Palu.

\section{Populasi dan Sampel}

Populasi dalam penelitian ini adalah semua pengunjung yang pernah melakukan pembelian tidak terencana pada Hypermart di Kota Palu. Adapun jumlahnya tidak diketahui serta tidak pasti, dikarenakan tidak adanya data pendukung yang mencari secara pasti bahwa pengunjung melakukan pembelian tidak terencana pada Hypermart di Kota Palu. Jumlah sampel yang diambil untuk mewakili populasi dalam penelitian ini sebanyak 60 sampel. Penentuan besarnya sampel pada penelitian ini merujuk pada teori Roscoeyang dikutip oleh Sugiyono (2015:133) yang menyatakan bahwa bila dalam penelitian akan melakukan analisis dengan multivariate (korelasi atau regresi 


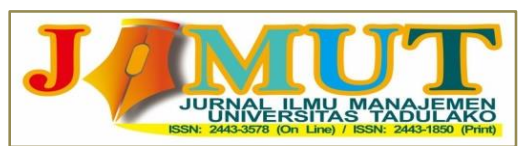

Vol. 6, No.3, September 2020, 243-251

berganda misalnya), maka anggota sampel adalah 10 kali dan jumlah variabel yang diteliti (variabel independen + variabel dependen).

\section{Uji Normalitas}

Uji Validitas digunakan untuk mengukur sah atau tidaknya suatu kuesioner. Menurut Sugiyono (2015:168) uji validitas adalah sejauh mana kehandalan sebuah alat ukur dalam mengukur apa yang seharusnya di ukur. Validitas juga merupakan derajat ketepatan antara data yang terjadi pada objek penelitian dengan data yang dapat dilaporkan oleh peneliti.Syarat minimum untuk dianggap memenuhi syarat adalah $r=0,3$. Jadi, korelasi atau hubungan antara butir dengan skor total kurang dari 0,3 maka butir dalam instrumen tersebut dapat dinyatakan tidak valid. Sebaliknya jika skor total menyatakan positif dan lebih besar dari 0,3 ( $r>0,3)$ maka instrumen tersebut dinyatakan valid atau sah.

\section{Uji Reliabilitas}

Penerapan uji reliabilitas adalah untuk mengetahui apakah alat pengumpulan data pada dasarnya menunjukkan tingkat ketepatan dan keakuratan atau konsisten intrumen tersebut dalam mengungkapkan gejala tertentu. Suatu instrumen dikatakan reliabel manakala memenuhi standar koefiesien alpha cronbach lebih besar 0,60. tersebut dinyatakan valid atau sah.

\section{Metode Analisis}

\section{Uji Normalitas}

Normalitas adalah untuk melihat apakah nilai residual terdistribusi normal atau tidak.Normalitas bertujuan menguji apakah dalam sebuah model regresi, variabel dependen (terikat), variabel independen (bebas) atau keduanya mempunyai distribusi normal ataukah tidak.Model regresi yang baik adalah distribusi data normal atau mendekati normal.

Deteksi normalitas dilakukan dengan melihat penyebaran data (titik) pada sumbu diagonal dari grafik. Dasar pengambilan keputusannya adalah:

1. Jika data tersebar disekitar garis diagonal dan mengikuti garis-garis diagonal, maka model regresi memenuhi asumsi normalitas.

2. Jika data menyebar jauh dari garis diagonal atau tidak mengikuti arah garis diagonal, maka model regresi tidak memnuhi asumsi normalitas.

2. Uji Multikolonieritas

Uji multikolinearitas bertujuan untuk melihat ada atau tidaknya korelasi yang tinggi antara variabel-variabel bebas dalam suatu model regresi linear berganda.Jika ada korelasi yang tinggi diantara variabel-variabel bebasnya, maka hubungan antara variabel-variabel bebas terhadap variabel terikatnya menjadi terganggu.

Uji multikolinearitas juga bertujuan untuk menghindari kebiasaan dalam pengambilan keputusan mengenai pengaruh pada uji parsial masing-masing variabel independen terhadap variabel dependen. Untuk itu digunakan cara mendeteksi adanya tindakan multikolinearitas dengan menggunakan Variance Inflation Factors (VIF) dengan cara melihat nilai VIF.

a. Jika nilai VIF-nya $<10$ maka dalam data tidak terdapat multikolinearitas,

b. Jika nilai VIF-nya > 10 maka dalam data tersebut terdapat multikolinearitas sehingga jika multikolinearitas terjadi maka cara mengatasinya adalah dengan mengeluarkan salah satu variabel yang mempunyai nilai korelasi lebih tinggi.

\section{Uji Heteroskedastisitas}

Uji heteroskedastisitas adalah untuk melihat apakah terdapat ketidaksamaan varians dari residual satu ke pengamatan yang lain. Model regresi yang memenuhi persyaratan adalah dimana terdapat kesamaan varians dari residual satu pengamatan ke pengamatan lain tetap atau disebut homokedastisitas.

Untuk mendeteksi adanya heteroskedastisitas dilakukan dengan melihat ada tidaknya pola tertentu pada grafik, dasar pengambilan keputusan adalah:

a. Jika ada pola tertentu, seperti titik-titik (points) yang ada membentuk suatu pola tertentu yang (bergelombang melebar kemudian menyempit). Maka telah terjadi heteroskedastisitas.

b. Jika tidak ada pola yang jelas, serta titik-titik menyebar diatas dan dibawah 0 pada sumbu Y, maka tidak terjadi heteroskedastisitas. 


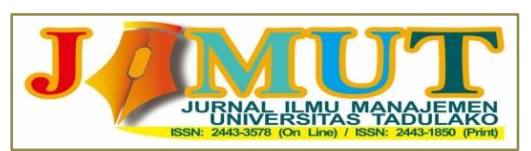

Vol. 6, No.3, September 2020, 243-251

4. Regresi Linear Berganda

Regresi linear berganda adalah untuk menguji pengaruh variabel promosi dan lingkungan toko terhadap pembelian tidak terencana pada Hypermart di Kota Palu, maka digunakan alat uji statistik yaitu regresi linear berganda yang dapat dirumuskan Sugiyono (2015:253)

Dimana :

$$
Y=a+b_{1} X_{1}+b_{2} X_{2}+b_{3} X_{3}+b_{4} X_{4}
$$

$$
\begin{array}{ll}
\mathrm{Y} & =\text { Pembelian tidak terencana } \\
\mathrm{X}_{1} & =\text { Variabel bebas Promosi } \\
\mathrm{X}_{2} & =\text { Variabel bebas lingkungan toko } \\
\mathrm{X}_{3} & =\text { Variabel bebas desain kemasan } \\
\mathrm{a} & =\text { Konstanta } \\
\mathrm{b}_{1}-\mathrm{b}_{4} & =\text { Koefisien regresi variabel bebas dari } 1 \text { sampai } 4
\end{array}
$$

\section{HASIL DAN PEMBAHASAN}

Penelitian ini menggunakan analisis regresi linear berganda dengan tujuan untuk menguji pengaruh promosi dan lingkungan toko terhadap pembelian tidak terencana. Maka untuk lebih jelasnya hasil analisis regresi linear berganda dapat dilihat pada tabel 2 di bawah ini:

Tabel 2 Hasil Uji Regresi Linear Berganda

\begin{tabular}{|l|c|c|c|c|}
\hline \multicolumn{4}{|c|}{ Dependent Variabel Y $=$ Pembelian Tidak Terencana } \\
\hline \multicolumn{1}{|c|}{ Variabel } & $\begin{array}{c}\text { Coefficients } \\
\text { Regression }\end{array}$ & $\begin{array}{c}\text { Standardized } \\
\text { Coefficient }\end{array}$ & Parsial & Sig. \\
\cline { 2 - 5 } & $\mathrm{B}$ & Beta & 0,937 & 0,353 \\
\hline (Constant) & 0,621 & & 3.250 & 0,002 \\
\hline Promosi $\left(\mathrm{X}_{1}\right)$ & 0,353 & 0,365 & 0,003 \\
\hline Lingkungan Toko $\left(\mathrm{X}_{2}\right)$ & 0,451 & 0,351 & 3.124 & \\
\hline $\mathrm{R}=0,885$ & & Sig. $\mathrm{F}=0,000$ & \\
$\mathrm{R}$ Square $(\mathrm{R} 2)=0,783$ & & $\mathrm{a}=0,05$ & \\
Adjusted R Square $=0,775$ & &
\end{tabular}

Sumber: SPSS 16.0 (Data Diolah Kembali)

Berdasarkan tabel 2 tersebut dapat ditulis dalam bentuk persamaan regresi linear berganda, maka untuk lebih jelasnya dapat dilihat sebagai berikut:

$$
\mathrm{Y}=0,621+0,353\left(\mathrm{X}_{1}\right)+0,451\left(\mathrm{X}_{2}\right)
$$

Berdasarkan persamaan di atas menunjukkan bahwa variabel independen yang dianalisis yaitu (X1 Dan X2) memberikan pengaruh positif terhadap variabel dependen (Y) yaitu pembelian tidak terencana pada Hypermart si Kota Palu, untuk lebih jelasnya maka dapat di lihat sebagai berikut :

1. Nilai konstanta sebesar 0,621 , yang mana menunjukkan apabila variabel promosi $\left(\mathrm{X}_{1}\right)$ dan lingkungan toko $\left(\mathrm{X}_{2}\right)$ bernilai nol maka variabel pembelian tidak terencana $(\mathrm{Y})$ yang berbelanja di Hypermart akan m eningkat sebesar 0,621 atau $62,1 \%$.

2. Nilai koefisien regresi variabel promosi $\left(X_{1}\right)$ sebesar 0,353 yang bertanda positif, hal tersebut menunjukkan bahwa adanya hubungan yang searah dengan variabel pembelian tidak terencana (Y). Artinya jika terjadi kenaikan pada variabel promosi $\left(\mathrm{X}_{1}\right)$ dengan asumsi variabel lingkungan toko $\left(\mathrm{X}_{2}\right)$ dalam kondisi konstan, maka variabel pembelian tidak terencana $(\mathrm{Y})$ akan meningkat.

3. Nilai koefisien regresi variabel lingkungan toko $\left(\mathrm{X}_{2}\right)$ sebesar 0,451 yang bertanda positif, hal tersebut menujukkan bahwa adanya hubungan yang searah dengan variabel pembelian tidak terencana $(\mathrm{Y})$. Artinya jika terjadi kenaikan pada variabel lingkungan toko $\left(\mathrm{X}_{2}\right)$ dengan asumsi 


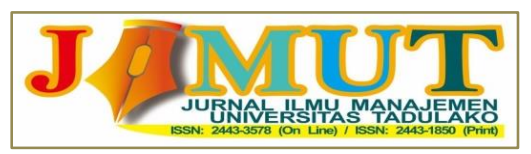

Vol. 6, No.3, September 2020, 243-251

variabel promosi $\left(\mathrm{X}_{1}\right)$ dalam kondisi konstan, maka variabel pembelian tidak terencana $(\mathrm{Y})$ akan meningkat.

4. Dapat diketahui korelasi dari variabel bebas dan variabel terikat (pembelian tidak terencana) pada Hypermart d Kota Palu adalah sangat kuat karena dalam penelitian ini menunjukkan nilai $\mathrm{R}=$ 0,885 atau $88,5 \%$ lebih besar dari 0,05 . Sedangkan nilai dari $R$ Square $\left(R^{2}\right)$ sebesar 0,783 atau $78,3 \%$. Artinya dapat disimpulkan bahwa variabel promosi $\left(\mathrm{X}_{1}\right)$ dan lingkungan toko $\left(\mathrm{X}_{2}\right)$ memiliki pengaruh terhadap pembelian tidak terencana $(\mathrm{Y})$ sebesar $78,3 \%$, sedangkan sisanya $21,7 \%$ dipengaruhi oleh variabel lain yang mana tidak disertakan dalam penelitian ini.

Tahap selanjutnya adalah menguji signifikan dari uji $\mathrm{F}$ antara variabel penelitian yaitu promosi $\left(\mathrm{X}_{1}\right)$ dan lingkungan toko $\left(\mathrm{X}_{2}\right)$ terhadap pembelian tidak terencana $(\mathrm{Y})$ dengan perhitungan menggunakan SPSS 16.0 dengan hasil sebagai berikut :

Berdasarkan tabel 3 di atas diperoleh Sig F adalah 0,000, artinya nilai tersebut lebih kecil dari nilai yang telah disyaratkan yaitu $a=0,05$ dengan tingkat kepercayaan 95\%. Maka dari itu dapat dinyatakan bahwa secara serempak berpengaruh signifikan terhadap pembelian tidak terencana pada Hypermart di Kota Palu.

Hasil Uji $t$ adalah untuk mengetahui apakah variabel $\left(\mathrm{X}_{1}-\mathrm{X}_{2}\right)$ secara parsial berpengaruh terhadap Y. Untuk lebih jelasnya dapat dilihat pada tabel 4 berikut:

Berdasarkan tabel 4 diatas Uji t pengujian variabel $\left(\mathrm{X}_{1}-\mathrm{X}_{2}\right)$ terhadap $\mathrm{Y}$ dijelaskan sebagai berikut:

1. Hasil Uji t untuk variabel promosi yaitu diperoleh nilai signifikan $0,002<a(0,05)$, dengan demikian variabel promosi secara parsial berpengaruh signifikan terhadap pembelian tidak terencana pada Hypermart di Kota Palu, dalam hal ini berarti hipotesis diterima kebenarannya.

2. Hasil Uji t untuk variabel lingkungan toko yaitu diperoleh nilai signifikan $0,003<a(0,05)$, dengan demikian variabel lingkungan toko secara parsial berpengaruh signifikan terhadap pembelian tidak terencana pada Hypermart di Kota Palu, dalam hal ini berarti hipotesis diterima kebenarannya.

Berdasarkan hasil pengujian serta analisis yang telah dilakukan pada penelitian ini membuktikan bahwa promosi dan lingkungan toko secara serempak berpengaruh signifikan terhadap pembelian tidak terencana pada Hypermart di Kota Palu. Berdasarkan tabel 3 didapat nilai sig F 0,000 < a $(0,05)$. Hasil penelitian ini sejalan dengan penelitian sebelumnya oleh Ria Arifianti (2015) yang menunjukkan bahwa promosi berpengaruh positif dan signifikan terhadap perilaku pembelian impulsif (pada Hypermart di Kota Bandung).Indah Tarakanita (2015) juga menyatakan bahwa store atmosphere memiliki pengaruh positif dan signifikan terhadap impulse buying.

Indikator variabel promosi dalam penelitian ini terdiri dari sampel, premium, rabat atau diskon. Pertama, promosi yang ditawarkan oleh Hypermart yaitu dimulai dengan pemberian sampel untuk beberapa produk yang bertujuan meningkatkan kepercayaan calon konsumen pada saat memilih produk, memberikan penganlaman konsumen sehingga akan merasa sadar terhadap produk yang ditawarkan, mendapatkan review langsung sangatlah penting dalam mengembangkan produk yang dibutuhkan konsumen yang mana Hypermart harus mencatat baik-baik dan jadikan sebagai bahan pertimbangan untuk selalu meningkatkan kualitas produk. Salah satu produk yang ditawarkan oleh pihak Hypermart adalah dengan menggunkan sampel yaitu produk kosmetik.

Kedua, promosi selanjutnya yang ditawarkan oleh Hypermart adalah sistem premium dan bertujuan sebagai pemberian imbalan yang berwujud secara langsung maupun tidak langsung atas dasar penggunaan produk atau mengunjungi tempat penjualan beberapa produk yang menggunakan sistem premium adalah produk sabun mandi, susu, makanan ringan.Ketiga, promosi yang ditawarkan oleh Hypermart yaitu dimulai dengan pemberian diskon untuk beberapa produk bahkan menjamin harga produk lebih murah dari yang lain, pemberian diskon untuk yang mempunyai kartu member dengan berbagai macam penawaran menarik serta masih banyak lagi promosi lainnya. Hal ini tentunya berdampak pada keputusan konsumen yang bisa saja terdorong untuk melakukan pembelian secara tidak terencana melalui promosi yang ditawarkan.

Berdasarkan penelitian yang dilakukan dapat diketahui bahwa proporsi pendapat dari setiap responden mengenai variabel promosi memiliki jumlah total nilai mean sebesar 4,08 yang artinya interpretasi dalam penelitian ini adalah dalam kategori baik. Hal ini menunjukkan responden setuju bahwa Hypermart harus lebih memperbanyak promosi pada barang yang dijual dengan alasan untuk mendapatkan barang yang diinginkan dari harga yang relatif lebih terjangkau. 


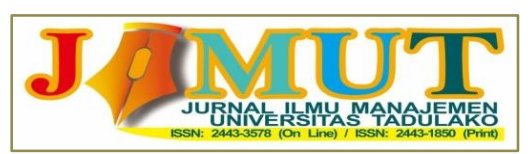

Vol. 6, No.3, September 2020, 243-251

Lingkungan toko adalah kegiatan yang dilakukan pemasar dengan mengkombinasikan dari beberapa elemen dalam hal meningkatkan nilai estetika sebuah toko.Selain itu dalam penelitian ini dimensi lingkungan toko terdiri dari beberapa indikator yaitu mulai dari bagian exterior, general interior, store layout sampai interiordisplay. Pertama, Hypermart menawarkan bagian depan dari sebuah toko yaitu papan nama (logo) sebagai tanda pengenal sebuah toko, pintu masuk sebagai suatu prasarana yang dapat mengundang konsumen untuk masuk dan melihat ke dalam toko sehingga mengurangi lalu lintas kemacetan keluar masuk konsumen, tempat parkir merupakan hal yang sangat penting bagi konsumen karena dengan tempat parkir yang luas, aman serta mempunyai jarak yang dekat dengan toko akan menciptakan lingkungan yang positif bagi toko.

Kedua, lingkungan toko selanjutnya yang ditawarkan pihak Hypermart adalah bagian keseluruhan di dalam ruangan yaitu pencahayaan dan pewarnaan ruang sebagai alat untuk mengarahkan atau menarik konsumen ke daerah tertentu sehingga dengan adanya tata cahaya yang baik akan menampilkan kualitas dan warna yang dapat membuat produk-produk yang ditawarkan terlihat lebih berbeda bila dibandingkan dengan keadaan yang sebenarnya. Volume musik, aroma dan suhu udara akan memberikan suasana yang lebih santai pada konsumen khususnya untuk menghilangkan kejenuhan, kebosanan maupun stres sehingga konsuemn dapat menghabiskan waktu lebih lama di dalam toko.Ketiga, fasilitas lingkungan toko yang ditawarkan Hypermart adalah penggelompokkan jenis barang terdiri dari penggelompokkan berdasarkan fungsinya dan motif pembelian yang mana penggelompokkan barang dirancang untuk menarik minat konsumen berbelanja dalam jumlah dan waktu tertentu yang dimiliki konsumen serta memudahkan untuk mencari apa saja yang konsumen inginkan maupuan butuhkan pada saat di dalam toko. Lalu lintas dalam toko juga sangat penting karena dapat menciptakan lingkungan toko yang efiesien dikarenakan luas lantai yang dapat digunakan untuk memajang produk lebih banyak serta konsumen dapat berbelanja dengan cepat.

Berdasarkan penelitian yang dilakukan dapat diketahui bahwa proporsi pendapat dari setiap responden mengenai variabel lingkungan toko jumlah total nilai mean sebesar 3,86 yang artinya interpretasi dalam penelitian ini adalah dalam kategori baik. Hal ini menunjukkan bahwa adanya kenyamanan yang dirasakan konsumen pada saat berbelanja dari segi lingkungannya baik di luar maupun di dalam toko.

\section{KESIMPULAN DAN SARAN}

\section{Kesimpulan}

Berdasarkan hasil dari penelitian ini, maka dapat disimpulkan bahwa:

1. Variabel promosi dan lingkungan toko secara simultan berpengaruh signifikan terhadap pembelian tidak terencana pada Hypermart di Kota Palu.

2. Variabel promosi secara parsial berpengaruh signifikan terhadap pembelian tidak terencana pada Hypermart di Kota Palu.

3. Variabel lingkungan toko secara parsial berpengaruh signifikan terhadap pembelian tidak terencana pada Hypermart di Kota Palu.

\section{Saran}

Berdasarkan kesimpulan yang telah dijabarkan sebelumnya, maka penulis dapat memberikan saran sebagai berikut :

1. Bagi perusahaan, diketahui dengan menggunakan strategi promosi dapat meningkatkan keputusan pembelian tidak terencana pada konsumen, sehingga pihak perusahaan harus lebih meningkatkan lagi kegiatan promosi seperti memberikan sistem premium (produk dengan harga yang lebih murah bahkan gratis yang mana sebagai insentif dari produk tertentu) dikarenakan hasil penelitian dari indikator variabel promosi yaitu premium memiliki nilai mean terendah.

2. Bagi perusahaan, diketahui lingkungan toko adalah salah satu hal terpenting yang dapat menunjang sebuah toko yang mana dapat membuat konsumen tertarik untuk datang berbelanja bahkan melakukan pembelian tidak terencana. Maka dari itu, perlunya meningkatkan kenyamanan dari segi lingkungan toko seperti penataan produk ataupun ruangan, memperbanyak banner atau poster yang menampilkan berbagai macam produk yang ditawarkan dikarenakan hasil penelitian dari indikator variabel lingkungan toko yaitu banner atau poster memiliki nilai terendah. 


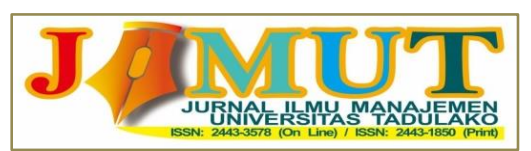

Vol. 6, No.3, September 2020, 243-251

3. Bagi penelitian, hendaknya dapat menambah variabel lain dikarenakan masih ada faktor-faktor lainnya yang mempengaruhi pembelian tidak terencana. Dengan menggunakan faktor-faktor lain yang belum diteliti pada penelitian ini, mungkin akan lebih bermanfaat bagi pihak perusahaan yang setidaknya dapat meningkatkan volume penjualan melalui pembelian tidak terencana serta perkembangan ilmu pengetahuan mendatang.

\section{REFERENSI}

Ali, Hasan. 2013. Marketing dan Kasus-Kasus Pilihan. CAPS (Center For Academic Publishing Service).Yogyakarta.

Arifianti, Ria, 2015. Pengaruh Promosi Terhadap Impulse Buying pada Hypermarket di Kota Bandung.Jurnal. Bandung.

Desrayudi. 2011. Pengaruh Price Discount, Bonus Pack, dan In-store Display Terhadap Keputusan Impulse Buying Pada SupermarketRobinson di Kota Padang. Fakultas Ekonomi Universitas Andalas.

Kharis, Ismu Fadli. 2011. Studi Mengenai Impulse Buying dalam Penjualan Online. Skripsi Universitas Diponegoro. Semarang.

Kotler, Philip, dan Gary Armstrong. 2014. Principles Of Marketing, Edisi Kelimabelas. Pearson Prentice Hall, New Jersey,USA.

Kotler, Philip dan Kevin Lane Keller. 2012. Marketing Mangement, Edisi 14. New Jersey: PrenticeHall Published.

Leba, Elizabet dan Suhermin. 2015. Pengaruh Atmosfer Gerai dan Promosi Terhadap Pembelian Impulsif Yang Dimediasi Emosi Positif.Jurnal Ilmu dan Riset Pemasaran. Sekolah Tinggi Ilmu Ekonomi Indonesia (STIESIA). Surabaya. Vol. 4, No. 1, Januari 2015.

Peter, J. Paul dan J.C. Olson. 2014. Edisi 9. Perilaku Konsumen dan Stategi Pemasaran, Salemba Empat. Jakarta.

Rook, D dan fisher, J.R.1995, "Normative influences on impulsive buying behavior", in Bearden, W. And Netemeyer, G.R. (Eds), Handbook of Marketing Scales, 2nd ed, pp.55-56.

Sari, D. A. T., dan Suryani, A. (2014). Pengaruh Merchandising, Promosi dan Atmosfir Toko Terhadap Impulse Buying. Jurnal.Fakultas Ekonomi dan Bisnis Universitas Udayana, Bali.

Schiffman dan Kanuk. 2010. Perilaku Konsumen Edisi 7. Jakarta: Indeks.

Sugiyono.2015. Metode Penelitian Kuantitatif, Kualitatif, dan Kombinasi (Mixed Methods), CV Alfabeta, Bandung.

Tarakanita, Indah, 2015. Pengaruh Promosi, Pelayanan Dan Suasana Toko Yang Nyaman Terhadap Keputusan Pembelian Tidak Terencana Pada Toko Mint Delta Plaza Surabaya, Skripsi, Fakultas Ekonomi Universitas Putra Surabaya.

Utami, Christina Widya. 2010. Manajemen Ritel, Edisi Kedua. Jakarta : Salemba Empat. 